\title{
LA INCURSIÓN DE LA FURA DELS BAUS EN EL TERRENO FÍLMICO: FAUSTO 5.0
}

\author{
Catalina Buezo Canalejo
}

Universidad Europea de Madrid

Fausto 5.0 (2001) cierra la trilogía sobre el mito fáustico iniciada por La Fura dels Baus con el montaje teatral F@usto versión 3.0 (1998) y continuada en el ámbito operístico con La condenación de Fausto (1999). La compañía no ha deseado teatralizar ni realizar una versión cinematográfica que remitiera a montajes previos de Fausto en el teatro ni en el cine (para las relaciones entre ambos lenguajes artísticos cf. José Romera Castillo, ed., 2002) - entre los pioneros destacan las siete variaciones que sobre el tema realiza Georges Méliès, desde Faust et Marguerite (1897) hasta Satan en prison (1907), y el Faust (1926), de F. W. Murnau es la mejor recreación cinematográfica y fuente de inspiración de historias como La caída de los dioses (1969), de Luchino Visconti o Mephisto (1981), de Klaus Mann)—.

El propósito del grupo ha sido, por el contrario, adaptar los contenidos al lenguaje audiovisual y acercarse a este mito de nuevo nacimiento en Occidente de tres formas distintas desde tres lenguajes apasionantes (www.lafura.com). Ya Goethe había realizado, influido por la obra anónima Historia del Dr. Johann Faustus (1587), diversas relecturas del tema del pacto diabólico a lo largo de su vida (desde el boceto juvenil del 
Urfaust, de 1790, hasta las partes primera, editada en 1808, y segunda, en 1833) y éste parece ser asimismo el empeño de La Fura dels Baus, compañía que aboga por un teatro faústico y que se considera a sí misma un Fausto del teatro (Buezo, 2003).

$\mathrm{Al}$ inicio del Evangelio de San Juan se lee «En el principio era la palabra», si bien al comienzo de la primera parte Fausto sustituye el logos por la acción y leemos: «En el principio era la acción». Ese culto a la acción por la acción, esa búsqueda inagotable, puede suponer el sustituir permanentemente unos afanes por otros sin detenerse en el disfrute del fugaz momento en el que llega a conocerse la suprema verdad, a vislumbrarse la Belleza. Esto es lo que le sucede a Fausto, a quien, sin embargo, acaba redimiendo el amor de Margarita; pero, hasta entonces, el personaje desea experimentar «todo lo que de la humanidad es patrimonio» (I Parte, acto único, escena IV, «Gabinete de estudio») sin percatarse de la tragedia de Margarita hasta que es demasiado tarde. Esa omnitud del Fausto goethiano, alejada de la lectura medieval de Marlowe, ya que en Goethe lo demoníaco está vinculado a una aspiración a lo total de tipo metafísico, la recoge La Fura dels Baus en sus montajes teatrales y operísticos del mito y la vuelve a tratar en Fausto 5.0.

Por su parte, si para algunos la figura angélica de Margarita encarna más a una pequeña burguesa provinciana que a una campesina del pueblo y, como una nueva Emma Bovary, lucha contra las convenciones de una sociedad que no le deja ser ella misma (París, 2001: 251-55), en Fausto 5.0 el eterno femenino da pie a la dualidad entre Julia, la ayudante de Fausto, y la innominada joven de la fiesta nocturna, con tintes de Lolita perversa. En último término para Fausto, como para Julia, el amor será una experiencia salvífica y se incide en la entrega de la mujer, que por amor libera al hombre de un destino incierto, y no en el sexo como detención en el camino (relación con la joven sin nombre). Si en la obra de Goethe muere a manos de Fausto Valentín, el hermano de Margarita, que la ha reprochado en público su conducta, y más tarde fallecen la madre de Margarita y su hijo recién nacido, en el filme se descartan todos estos episodios, así como la condena a muerte de Margarita al término de la primera parte, y la trama argumental se centra en la aventura interior del protagonista, que tiene asimismo funestas consecuencias (la muerte de uno de sus colegas médicos). Del personaje femenino queda, pues, su carácter de redención (Julia) o de aventura esporádica dentro de un universo de tipo onírico en el que aparecen actos asociados al rito como las fiestas 
ligadas a la cultura de masas y a la música pop (en la descrita en Fausto 5.0 conocerá Fausto a la adolescente que remite a la Margarita casi niña goethiana).

Recuérdese que en la versión teatral F@usto 3.0 ve Fausto por primera vez a Margarita en una macrodisco y le pide a Mefisto, como ahora hace el doctor, que se la consiga en solo veinticuatro horas. Nótese también cómo en la segunda parte de este montaje aparece Fausto en estado vegetativo, como los pacientes del médico y él mismo, y sueña con un cuerpo en el que materializar sus sueños. Si aquí los logros digitales estribaban en la relación fluida entre el actor, que emerge de la imagen, de la virtualidad, y las proyecciones, y a partir de ahí otros logros conceptuales fueron la manipulación del tiempo o el tratamiento de la luz, en el filme sobresale la extrañeza resultante del enmascaramiento de lo cotidiano, de lo conocido, como queda de manifiesto en la presentación de una Barcelona apuntalada, posindustrial, de tonos ocres, cercana estéticamente a la urbe retratada en Blade Runner. Ya no nos situamos en un Los Ángeles irreconocible, sino en una megápolis multirracial en la que, entre materiales de desecho, pululan seres desposeídos que descubrimos según avanza el coche en el que Santos (Mefistófeles, Eduard Fernández) conduce a Fausto (Miguel Ángel Sola) hasta el hotel en el que se aloja, cuya fachada queda oculta detrás de andamios, plásticos y cuerdas.

Cuando, en la segunda parte del Fausto de Goethe, Fausto llama a Mefisto y a sus hombres para que, sin ver ni saber los detalles, los ancianos Baucis y Filemón desaparezcan (Goethe vislumbra los problemas del mundo que nace en el siglo XIX) éste es el tipo de mal de nuestra época: indirecto, impersonal, llevado a cabo por instituciones y organizaciones complejas que imponen el pensamiento único, al parecer el complemento de la globalización. ¿Es posible ser como Baucis y Filemón hospitalarios con las multitudes que desean acceder al Primer Mundo, con esos seres desposeídos, o hay que incendiar el pasado, olvidarse de la ética y, buscando la eficacia, destruir la cabaña simbólica de este matrimonio? (Berman, 1991: 259-60). Antes se pensaba que de la transformación del mundo exterior brotaría la mejora de los hombres. Era el ideal de Fausto, que tendía a simplificar y también a ser determinista en exceso, pero en definitiva era un ideal de realización humana. Hoy día sabemos que una sociedad diferente requiere un nuevo modelo de desarrollo tecnológico, encaminado no a la producción de armas y mercancías. Esta construcción, apunta Carlos París (2001: 287), será posible cuando los hoy desposeídos accedan al poder. 
No faltan llamas en el infierno doméstico de los malos pensamientos - se suceden en el filme imágenes de prostitución, encapuchados, robos, gente pendiente de los edificios- que se dan la mano con la psique de Fausto, médico que tiene a su cargo a pacientes terminales reducidos a números en un hospital que se asemeja a un hangar. Como en los casos de los que se ocupa, a Fausto le ronda ya antes de su viaje la muerte: desea suicidarse lanzándose a la vía del tren, pero se cruza en su mente el deseo de salvar a un niño que parece correr la misma suerte. La aparición de Julia (la cara bondadosa de Margarita, Najwa Nimri) le impide asimismo realizar su deseo, que pervive en el vagón tanto en la toma de la anciana que deja a su cargo una maleta como en la superposición de imágenes que proyectan sobre su rostro la radiografía de un cráneo. La puerta que le refleja, cerrándose en dos, da cuenta de la dicotomía en la que se encuentra y los operarios que en el lugar de destino limpian el tren de vísceras y de sangre (lo que enlaza con el magnífico travelling retro del inicio del filme) aluden a un fin de trayecto, de vida, sangriento. Los personajes parecen afrontarlo de manera aséptica (la firma limpia del doctor en el expediente de Renol, que recoge el plano de detalle del arranque) o emocional (la madre de Renol, reducida a sus funciones primarias, llora, reza y orina ante su hijo entubado).

Pero hay otras formas de mirar el mundo. En Barcelona se tropieza con el doctor Fausto Santos, ex paciente al que ocho años atrás le extirpó el estómago y sigue vivo, porque, y así se lo indica a Fausto, la mera voluntad de vivir es más poderosa que la muerte. En el libro de Goethe Fausto, aun siendo muy sabio, no está contento con sus conocimientos e invoca directamente a Mefistófeles; en el filme de La Fura dels Baus, Fausto es infeliz y su subsconsciente es el que reclama la presencia de Mefistófeles, encarnado en el charlatán Santos Vella — que repite el chiste fácil «como mozarella, con dos eles» y la frase «Solo quiero hacerle feliz, doctor»-

No hay ninguna mención a la divinidad a lo largo de la película y el diablo lleva chupa de cuero y adopta desde el principio una actitud chulesca y aun grosera que en el fondo el cortés y educado Fausto desprecia. No obstante, no puede escapar a la seducción que sobre él ejerce este personaje, que le entrega su tarjeta de presentación en varias ocasiones y acaba haciéndose imprescindible en el descenso a los infiernos de Fausto, cuyos deseos y pensamientos Santos cumple. Así, Fausto asiste perplejo a la curación casi instantanea de Renol, uno de sus desahuciados pacientes, y, a partir de aquí, sin conocer todavía el poder de Santos, le califica de 
genio y olvida el incidente del hotel (tiene relaciones con una joven prostituta que luego resulta ser hija del propio Santos).

A medida que Santos Vella reaparece Fausto nos desvela su lado más desenfadado y su apariencia formal queda en segundo plano. De esta forma, se desinhibe en un domicilio particular - pone la música a todo volumen, rompe un jarrón de porcelana con un palo de golf y extiende seguidamente un talón sin fondos a los incrédulos propietarios que le encuentran in fraganti - y acude luego a una macrofiesta psicodélica en la que, bajo los efectos del alcohol, desea a una adolescente - la Margarita de Goethe se desdobla, como se ha dicho, en la figura salvífica de Julia, de pelo claro, y en la de la mujer niña de piel blanquísima y cabello oscuro que le lleva a la perdición, literalmente acompañada de la bajada a los sótanos del edificio-.

Allí, mientras hace el amor con la joven de forma violenta e incluso sádica, comprende que vive inmerso en una pesadilla: el escenario se convierte en un quirófano improvisado y sucio y Fausto, que «opera», maniobra, en el cuerpo de la joven, despierta en una mesa de operaciones al tiempo que un perro negro le devora las entrañas en busca de la glándula del mal que con tanto ahínco el propio Fausto ha perseguido en sus investigaciones (y sobre la que ha hablado en un congreso fantasmal en el que, siguiendo el mismo juego de errores, las imágenes pornográficas de una cinta de vídeo sustituyen al caso clínico grabado y Fausto queda en ridículo, burlado por Santos, delante de sus colegas). A su llegada al hotel otro de sus sueños se ha cumplido: la muerte del doctor que, en su opinión, provocó el error, una muerte que le acusa desde las paredes manchadas con sangre de su propia habitación.

Encarcelado, y ante la perspectiva de que Santos pueda dañar a Julia, que desde Madrid se desplaza a reunirse con él, Fausto sufre lo inimaginable, consciente de estar encadenado mentalmente a Santos, la sombra mefistofélica de este especialista en enfermedades terminales que deambula desconcertado por Barcelona, a donde acude a dar una conferencia.

En el filme, Fausto llega a desear la muerte de Santos (perece repentinamente en accidente automovilístico) y acaba literalmente firmándola: al poner la rúbrica en su expediente, abierto de forma inexplicable a pesar de su defunción, se cierra ese caso clínico de manera definitiva. La imagen de Fausto saliendo de las llamas significa su salida del infierno y, por ende, su entrada en la vida. Porque Santos no sólo ha dado vía libre a sus 
deseos, sino que también le ha devuelto la humanidad perdida. El amor de Fausto hacia Julia le redime de sí mismo y los tonos cálidos hacen su aparición en el tramo final de la cinta. Fausto, el eterno insatisfecho, se detiene a contemplar la belleza del mundo en el escote de Julia. El personaje consigue entonces ver la luz que ésta simboliza. Julia, a su vez, percibe que sus sentimientos chocan con su antiguo papel social, pero, puesto que son legítimos, crece gracias al amor y la eficiente ayudante deja paso a la futura pareja del doctor.

En el terreno del lenguaje fílmico, las metáforas del tren, de la calavera o de las escaleras caróneas, aun no siendo novedosas, sirven para que se respete la atmósfera del relato goethiano, difícil de llevar a la gran pantalla debido a la densidad de los diálogos, a los continuos saltos de espacio y tiempo y a su carácter híbrido, situada a medio camino entre la novela y el teatro. En algunos momentos esta ópera prima de La Fura dels Baus peca de excesos en el montaje, de una narración reiterativa, aun cuando el lenguaje visual y la música digital, habituales pinceladas fureras, cumplen aquí con su propósito (notables son las escenas en el hospital, con estética de hangar y tabiques de plástico con enormes números), es decir, sirven para expresar el ritmo de vida moderno y la insatisfacción del hombre contemporáneo que Fausto ejemplifica.

En este sentido, Santos (Mefisto) se aleja de la interpretación medieval, cristiana, que lo convierte en un personaje condenable y su ambigüedad nos habla de la de nuestro propio mundo, en el que los conceptos del bien y del mal se han diluido. La compañía, de claro bagaje teatral, se adentra con su primera película en otro medio y, sin renunciar a su discurso, realiza, ayudada de nuevo de la tecnología audiovisual, una película de bajo presupuesto (se empezó a rodar el 5 de febrero de 2001 y se terminó de rodar en nueve semanas; se contó con 500 millones de pesetas y se creó ex profeso la productora Fausto Producciones, en colaboración con Cartel), que consigue, sin perder el sentido del texto original, el propósito de involucrar en esta versión libre del Fausto goethiano al espectador, incómodo en su butaca: a la tensión creada por Santos se suma la de la atmósfera envolvente, onírica, de una ópera prima que se sigue con atención hasta el final.

Los directores fueron Alex Ollé y Carlos Padrissa, miembros de La Fura dels Baus, y el reputado realizador publicitario Isidro Ortiz. Escribió el guión el guionista y director Fernando León de Aranoa (Premio Goya 
en 1997 al mejor realizador novel, Concha de Plata en San Sebastián en 1998 y Goya al mejor guión y a la mejor dirección por Barrio). Los personajes principales fueron interpretados por Miguel Ángel Solá (Plenilunio, Sé quién eres), Eduard Fernández (Los lobos de Washington) y Najwa Nimri (Abre los ojos, Los amantes del círculo polar).

El filme se proyectó, fuera de concurso, en la sección oficial de la 58 Muestra de Cine de Venecia y Eduard Fernández recibió, por el papel de Santos, un Premio Goya a la mejor interpretación masculina protagonista y el Premio al mejor actor en el Festival de Sitges de 2001 (www.clubcultura.com/clubcine/fausto/fausto3.htm). La habitual transgresión furera no afecta aquí al plano formal — no hay efectos especiales ni yuxtaposición vertiginosa de acciones-, sino al del contenido: se ha explorado en el mundo de los deseos dentro del género del thriller y situado la acción en un tiempo indefinido. Se ofrece la visión de una Barcelona multicultural en la que conviven elementos estéticos del pasado y de un supuesto futuro sin echar mano de las formas de la ciencia-ficción.

\section{FICHA ARTÍSTICA}

$\begin{array}{ll}\text { Fausto } & \text { Miguel Ángel Solá } \\ \text { Santos } & \text { Eduard Fernández } \\ \text { Julia } & \text { Najwa Nimri } \\ \text { Margarita } & \text { Raquel González } \\ \text { Quiroga } & \text { Juan Fernández } \\ \text { Marta } & \text { Irene Montalà } \\ \text { Bielsa } & \text { Pep Molina } \\ \text { Mujer ojerosa } & \text { Cristina Piaget } \\ \text { Anciana } & \text { Carmen Contreras } \\ \text { Presentador } & \text { Keke } \\ \text { Daisy } & \text { Teresa Manresa } \\ \text { Fierro } & \text { Óscar Borrás. }\end{array}$




\section{FICHA TÉCNICA}

Fausto 5.0, proyecto de La Fura dels Baus producido por Fausto producciones y Cartel

Directores

Producción ejecutiva

Productores asociados

Productor delegado

Argumento

Guión

Directora de producción

Director de fotografía

Directora de arte

Image design concept

Vestuario

Maquillaje

Peluquería

Sonido

Montaje

Efectos digitales

Casting
Isidro Ortiz, Alex Ollé y Carlos Padrissa

Ramón Vidal, Alicia Gallardo y

Eduardo Campoy

Jordi Mendieta, Mario Pedraza, Rafael Martín Sanz y Fernando Martín Sanz

Fernando Marqueríe

Fernando León de Aranoa, Alex Ollé, Isidro Ortiz y Carlos Padrissa

Fernando León de Aranoa

Aintza Serra

Pedro del Rey

Leo Casamitjana

Chu Uroz

Antonia Marqués

Concha Rodríguez

Quim Grau

Albert Manera

Luis de la Madrid

Telson Dpto. de cine

Sara Bilbatúa. 


\section{REFERENCIAS BIBLIOGRÁFICAS}

BERMAN (1991). Se desvanece en el aire. Madrid: Siglo XXI.

Buezo, Catalina [2003, en prensa] «La Fura dels Baus: acción y ritual dionisíaco». En Actas del 14 Congreso de la Asociación Alemana de Hispanistas, Ratisbona, 6-9/3/2003.

- (2004). «La Fura dels Baus», un teatro fáustico y un Fausto del teatro: F@usto versión 3.0. En Actas del XIII Seminario Internacional sobre Teatro, prensa y nuevas tecnologías, José Romera Castillo (ed.), 333343. Madrid: Visor Libros.

CIATRE: www.ciatre.com/pagines/catala/fura.html

EURÍPIDES (1991). Tragedias completas III. Madrid: Cátedra (Letras Universales).

FAUSTO de La Fura dels Baus: www.clubcultura.com/clubcine/fausto/fausto3.htm

FAUST 3.0 FMOL: www.iua.upf.es/-sergi/FMOL/fmoltrio/index-fmol.htm

Frameset for Video Discussion, lafura.fib.upc.es/wip/eng-debate-videofrm.htm

García Gual, Carlos (1997). Diccionario de mitos. Barcelona: Planeta.

GoETHE, Johann Wolfgang von (1991). Fausto, edición de Manuel José González y Miguel Ángel Vega. Madrid: Cátedra (Letras Universales).

Guggenheim. La Fura dels Baus llenará de luz y sonido los alrededores del museo Guggenheim: www.diario-elcorreo.es/guggenheim/textos/fura.html

La Fura Dels Baus -Biosfura, Web Oficial: www.lafura.com

La Fura Dels Baus Citywide 1991: www.creativetime.org/citywide/past-proj/fura.html

La Fura Dels Baus (1998). Dossier de prensa F@usto 3.0 y F@ust versión 3.O. Libro del estreno del montaje. Barcelona: La Fura dels Baus.

LA Fura Dels Baus. El Furamòbil: www.labisbal.org/firacirc/baus.htm 
LA Fura Dels Baus. Work in Progress: lafura.fib.upc.es/wip/engPrincipal.htm.

PARís, Carlos (2001). Fantasía y razón moderna. Don Quijote, Odiseo y Fausto. Madrid: Alianza.

Romera Castillo, José (ed.) (2002). Del teatro al cine y la televisión en la segunda mitad de siglo XX. Madrid: Visor Libros.

VILCHES DE FRUTOS, Mª. Francisca (ed.) (2001). Teatro y cine: la búsqueda de un nuevo lenguaje expresivo. Boulder: Anejo de Anales de Literatura Española Contemporánea, vol. 26, Isue I. 